\title{
MODULATING EFFECT OF CAMEL'S MILK ON ALLOXAN-INDUCED EXPERIMENTAL DIABETES IN LABORATORY ANIMAL MODEL
}

\author{
RASHA G. SAYED*; AHMED ABDEL-HAMEID AHMED*; NASR-ELDIN M. AREF** and \\ MOHAMMED SAYED* \\ * Department of Food Hygiene, Faculty of Veterinary Medicine, Assiut University, Assiut 71526 - Egypt. \\ ** Department of Animal Medicine, Faculty of Veterinary Medicine, Assiut University, Assiut 71526 - Egypt. \\ E-mail: nasreldeen.aref@vet.au.edu.eg
}

Received at: $22 / 4 / 2013$

Accepted:29/4/2013

\section{ABSTRACT}

The present study was conducted to evaluate the hypoglycemic effect of camel's milk in alloxan-induced diabetic animal model compared to control and cow's milk receiving groups. This study was carried out on thirty five female white albino rats and divided into 2 main groups: optimizing and experimental group. Optimizing group $(n=20)$ was used to determine the optimal dose of alloxan to induce diabetes in a pattern of dose response relationship. This group was divided into four subgroups, sG1 to sG4, ( $\mathrm{n}=5$ each). sG1, sG2, sG3, and sG4 were injected intraperitoneally with alloxan monohydrate at a dose 100, 140, 180 and $200 \mathrm{mg} / \mathrm{kg} \mathrm{B.W.,}$ respectively. Experimental group $(n=15)$ was divided into three subgroups $(n=5$ each) as following: diabetic rats receiving no treatment and acts as a positive control (sG1), diabetic rats receiving camel's milk (sG2) and diabetic rats receiving cow's milk (sG3). Their blood glucose levels (BGLs) were estimated at weekly interval for 5 consecutive weeks. A baseline BGL was determined before conducting the experiment and it was $79.85 \pm 4.2 \mathrm{mg} / \mathrm{dl}$. The results showed that $140 \mathrm{mg} / \mathrm{kg} \mathrm{B}$.W. of alloxan was the optimal dose to induce stable diabetes in the optimizing group. In the experimental group, the initial mean BGLs for sG1, sG2, and sG3 were $399.5 \pm$ $18.3,429.4 \pm 66.4$ and $404.6 \pm 53.6 \mathrm{mg} / \mathrm{dl}$, respectively and after $5^{\text {th }}$ week there were $488.2 \pm 20.8,308.28 \pm 52.2,519.8 \pm 131.5 \mathrm{mg} / \mathrm{dl}$ respectively. Most diabetic animals that received cow's milk exhibits severe signs of diabetes at $4^{\text {th }}$ week of experiment and died by $5^{\text {th }}$ week while animals that received camel's milk showed marked improvement and one of them exhibited normal BGL by the end of experiment. Our findings suggested that administration of camel's milk was effective in improvement of the alloxan-induced diabetic rats and recommended as nutraceuticals supplement in diabetic patient.

Key Words: Diabetes, Alloxan, BGL, Camel's milk, Laboratory animal

\section{INTRODUCTION}

Diabetes mellitus is a global major health problem (Macedo et al., 2002), characterized by metabolic disorder and hyperglycemia results from insufficient insulin hormone with or without abnormal resistance to insulin effect (Tirerney et al., 2002). It becomes the third killer of mankind after cancer and cerebrovascular \& cardiovascular diseases (Li et al., 2004). It is also one of major endocrine dysfunctions in pet animals (Davison et al., 2005; Catchpole et al., 2008).

In modern medicine, no satisfactory effective therapy is available to cure diabetes mellitus, although it can be managed by insulin treatment. Pharmaceutical drugs used in diabetic therapy are effective; however they may have undesirable side effects or contraindications. Additionally, they are too expensive and several patients might have needle phobia (Pari and Satheesh, 2004). All these factors force diabetic patients to adopt alternative therapies. Therefore, the research for more effective and safer hypoglycemic agent has continued to be an area of an active research (Lemhadri et al., 2004; StanelyPrince et al., 2004).

Beside the nutritive value of camel's milk which is extremely well adapted for human requirements, it appears to be an additional factor as medical or natural healing properties. Using camel's milk for 
treatment is itself a point of contention. Historically camel's milk has been used for a number of medical problems and according to FAO, camel's milk is the healthiest milk produced by animals (Yagil, 1982). Its consumption may help in reducing the nutritional deficiencies and morbidities in adult communities (Singh et al., 2009). It was found that one of camel's milk proteins has many characteristic similarities with insulin (Beg et al., 1986). Radioimmunoassay tests of camel's milk has revealed high concentration of insulin i.e. 52 micro unit/ml (Agrawal et al., 2003).

Against this background, the present study was carried out to investigate the therapeutic effect of camel's milk on diabetes mellitus in diabetic-induced animal model and compare its effect with the cow's milk.

\section{MATERIALS and METHODS}

\section{Animals}

Thirty five female white albino rats of approximately same age group (8-9 weeks old) weighing between 120-150 g were included in this study. All rats were obtained from Laboratory Animals House, Faculty of Medicine, Assiut University. Standard operating procedures for handling of animals in compliance with the guidelines and recommendations for the Institutional Animal Care and Use Committee (IACUC) of Assiut University were adopted. Animals were kept on commercial rat chow and water ad libitium for one week before initiating the experiment to acclimatize the laboratory condition (temperature $22{ }^{\circ} \mathrm{C}$, relative humidity $50 \%, 12 \mathrm{~h}$ light and $12 \mathrm{~h}$ dark) (Agrawal et al., 2005).

\section{Milk samples}

Camel's milk was obtained from she-camels (Camelous dromedaries) belonging to individuals, while cow's milk was obtained from Veterinary Teaching Hospital, Assiut University-Egypt.

Both types were used without any treatment or dilution. The clot on boiling and acidity of the milk samples were checked to monitor the freshness.

\section{Experimental Design}

\section{Animal groups}

a) Optimizing group: 20 rats were used to determine the diabetic dose of alloxan monhydrate (ELGomhorya Co, Egypt) that develops stable diabetes without toxicity. Dose-response relationship was established at 100, 140, 180 and $200 \mathrm{mg} / \mathrm{kg} \mathrm{B}$.W. Each dose was administered into 5 rats.

b) Experimental group: 15 rats were used to test the effect of camel's and cow's milk in diabetic rats.

1) Subgroup 1: Five diabetic rats received no milk (positive control).
2) Subgroup 2: Five diabetic rats received camel's milk

3) Subgroup 3: Five diabetic rats received cow's milk

Milk was given to them daily by oral cannula $(20 \mathrm{ml})$ in additions to free milk ad libitium.

2. Experimental induction of diabetes and studying the antidiabetic effect of camel's and cow's milk.

2.1. Determination of the diabetic dose of alloxan monohydrates in dose response relationship

Alloxan monohydrate has selective destructive cytotoxic effect on the cells of pancreas (Bolaffi et al., 1986). To induce stable diabetes, briefly four different doses (100, 140, 180 or $200 \mathrm{mg} / \mathrm{kg} \mathrm{B.W.)} \mathrm{of}$ alloxan monohydrate dissolved in sterile normal saline were freshly prepared and each dose was injected intraprotenially (Fig. 1) into overnight (16-18 h) fasted rats $(\mathrm{n}=5)$ at $0.5 \mathrm{ml} / \mathrm{rat}$. Animals were kept on glucose $5 \%$ for the next $24 \mathrm{~h}$ to avoid hypoglycemia that might be occurred (Tatiya et al., 2010).

\subsection{Studying the antidiabetic effect of camel's and cow's milk}

Fifteen rats were injected with the optimal dose of alloxan (140 mg/kg B.W.). These animals were divided into 3 subgroups (5 rats each): $1^{\text {st }}$ subgroup received no milk (positive control), $2^{\text {nd }}$ group received camel's milk and $3^{\text {rd }}$ one received cow's milk (Fig. 2). All animals were weekly monitored for their BGLs until the end of the study ( $5^{\text {th }}$ weeks). Succumbed rats before 5 weeks were recorded as unrecovered diabetic rat.

\section{Blood samples}

Blood samples were collected $(0.5 \mathrm{ml} /$ collection $)$ weekly from the retro-orbital plexus of all animals using heparinized micro-capillary glass tubes into a clean dry plain Epindorf's tubes (Fig. 3). Samples were left to clot at room temperature for $30 \mathrm{~min}$ and centrifuged for $10 \mathrm{~min}$ at $4500 \mathrm{rpm}$ for separation of the sera. Sera were aspirated by a micropipette into stopper Epindorf's tubes and BGL were determined immediately using glucose test kits.

\section{Determination of blood glucose level (BGL)}

Glucose oxidase method was adopted to determine BGL spectro-photometerically at $505 \mathrm{~nm}$ using a commercially available test kit (Biotechnology, Egypt).

5. Statistical analysis: Generated data of BGL from various groups were subjected to statistical analysis using SPSS (1999) program for windows version 10.0.1 (SPSS Inc., Chicago, IL) for calculation of mean and standard error. 


\section{RESULTS}

Results of the effect of different doses of alloxan monohydrate on BGL were presented in Table 1 and depicted in Fig. 4 \& 5 while the results of the effect of cow's milk on diabetic group was presented in Table 2 and Fig. 6 compared to the modulating effect of camel's milk (Table 2 and Fig. $7 \& 8$ ).

Table 1: The Effect of Different Doses of Alloxan Monohydrate on Blood Glucose Level

\begin{tabular}{ccccc}
\hline Dose (mg/kg) & $\begin{array}{c}\text { No. of } \\
\text { rats }\end{array}$ & $\begin{array}{c}\text { Mean } \pm \text { SE of } \\
\text { BGL (mg/dl) }\end{array}$ & Morbidity rate (\%)* & Mortality rate (\%)** \\
\hline $\mathbf{1 0 0}$ & 5 & $83.69 \pm 3.2$ & 0 & 0 \\
\hline $\mathbf{1 4 0}$ & 5 & $399.48 \pm 18.3$ & 80 & 0 \\
\hline $\mathbf{1 8 0}$ & 5 & $746.50 \pm 21.9$ & 100 & 100 \\
\hline $\mathbf{2 0 0}$ & 5 & Out of range & 100 & \\
\hline
\end{tabular}

* Morbidity rate is the number of animals showed high BGL/total number of animals

N.B. Rats gave fasting blood glucose level $\geq 250 \mathrm{mg} / \mathrm{dl}$ and remained alive after 2 weeks were considered positive stable BGL and included in the presented study.

** Mortality rate is the number of dead animals/total number of animals

Table 2: Weekly Mean \pm SE of Blood Glucose Level (mg/dl) in Different Groups

\section{Diabetic}

\begin{tabular}{cccc}
\cline { 2 - 4 } Time/Group & $\begin{array}{c}\text { Positive (diabetic) } \\
\text { control }\end{array}$ & $\begin{array}{c}\text { Diabetic receiving } \\
\text { Camel's milk }\end{array}$ & $\begin{array}{c}\text { Diabetic receiving } \\
\text { Cow's milk }\end{array}$ \\
\hline day 1 & $399.48 \pm 18.3$ & $429.4 \pm 57$ & $404.6 \pm 53.6$ \\
\hline day 7 & $420.3 \pm 24.3$ & $410.1 \pm 66.4$ & $469.7 \pm 46.3$ \\
\hline day 14 & $434.6 \pm 25.4$ & $362.8 \pm 60.5$ & $527.6 \pm 67.7$ \\
\hline day 21 & $447.1 \pm 25.9$ & $340.1 \pm 62.4$ & $519.8 \pm 131.5$ \\
\hline day 28 & $488.2 \pm 20.8$ & $308.28 \pm 52.2$ & - \\
\hline
\end{tabular}




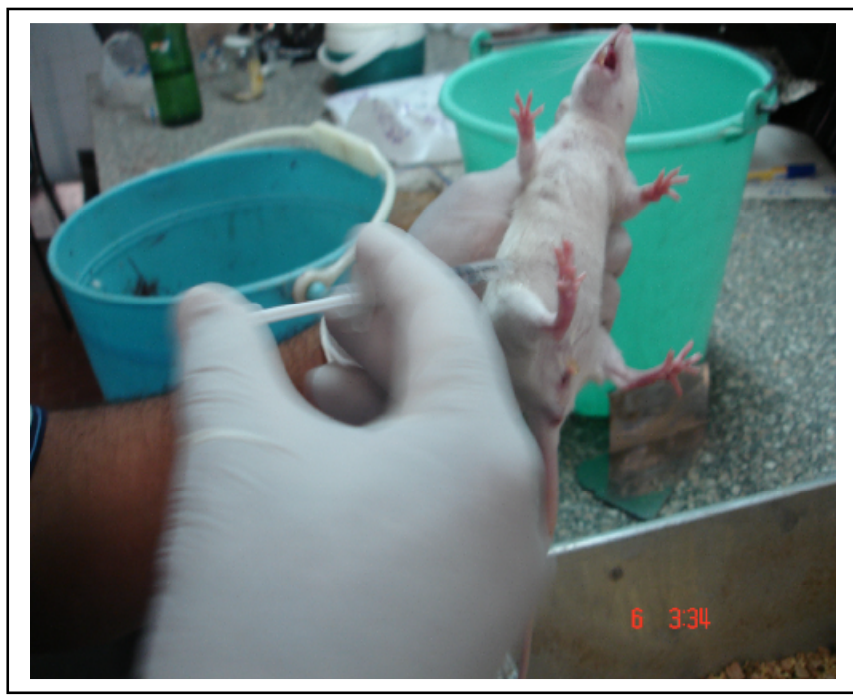

Fig. 1: Intraperitoneal injection of alloxan monohydrate in white albino rat

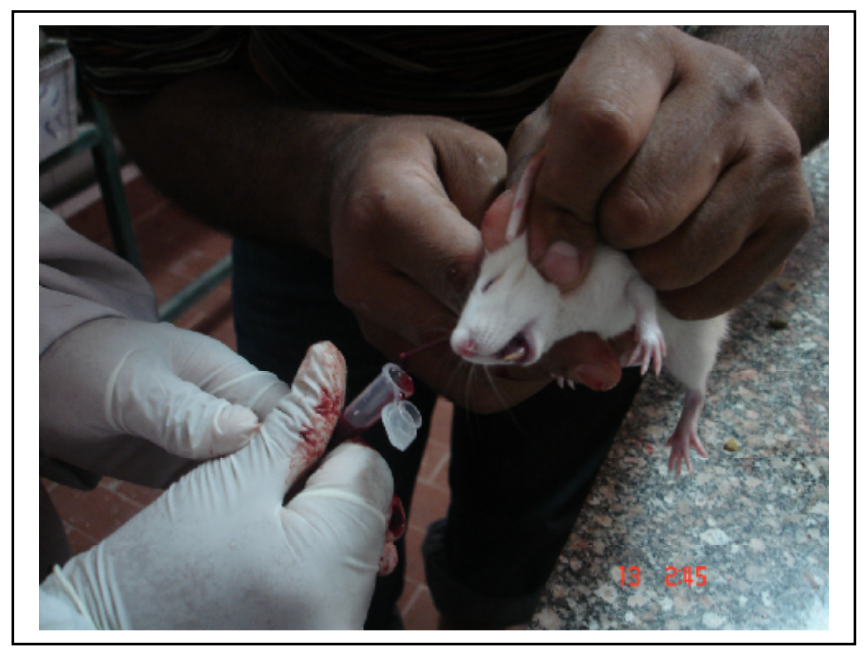

Fig. 3: Collection of blood sample from the retroorbital plexus using heparinized microcapillary glass tubes \& plain Epindorf's tube in white albino rat

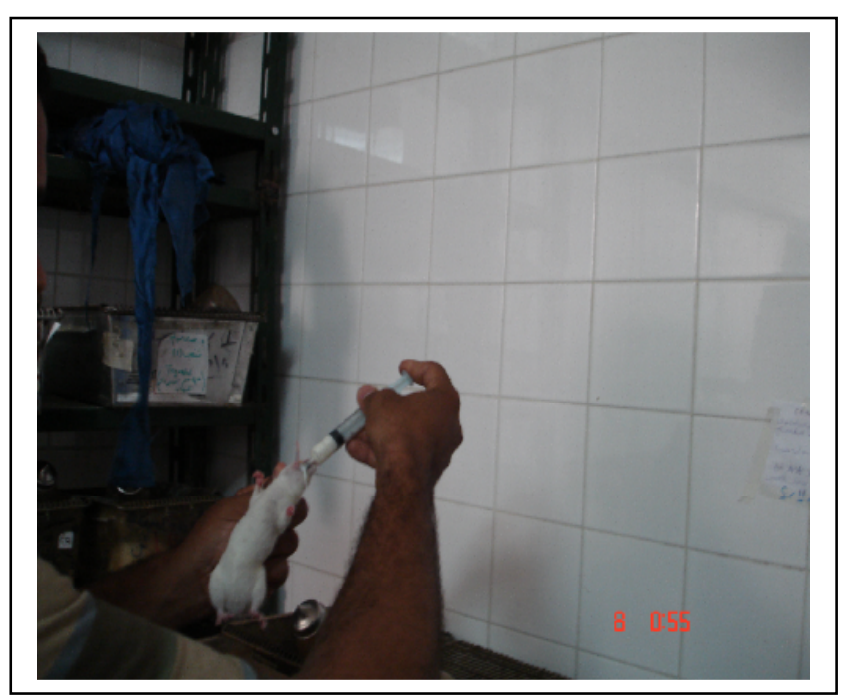

Fig. 2: Oral feeding of tested milk sample in white albino rat

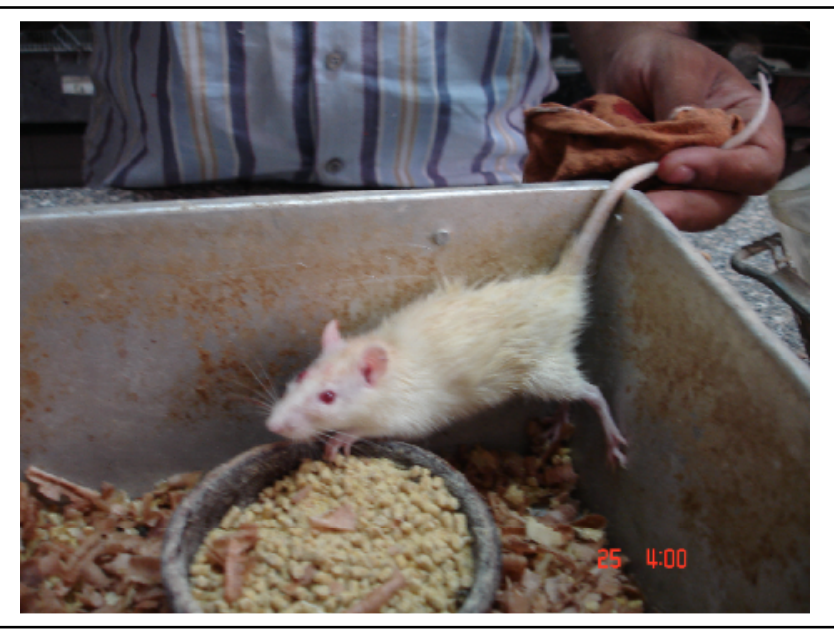

Fig. 4: Female white albino rat of (8- week- old exhibited signs of diabetes, rough coat, polyurea and polydepsia) 


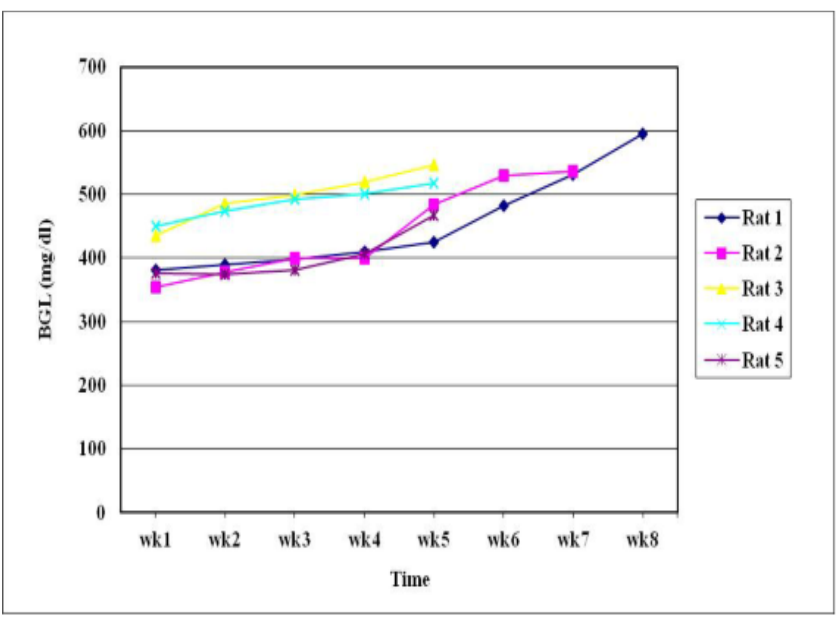

Fig. 5: Time-course evaluation of blood glucose level at $140 \mathrm{mg} / \mathrm{dl}$ Alloxan monohydrate in 5 rats (Positive control group)

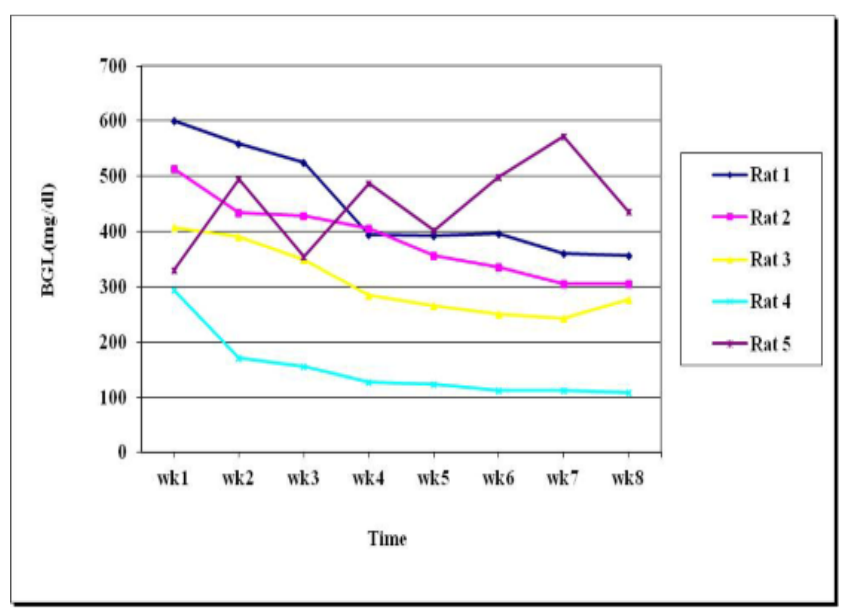

Fig. 7: Time-course evaluation of antibiabetic effect of camel's milk on 5 rats

\section{DISCUSSION}

Test 1: Optimizing the dose of alloxan monohydrate

Before initiating the experiment, the baseline for BGL was estimated in healthy animals to be $79.58 \pm$ $2 \mathrm{mg} / \mathrm{dl}$. Alloxan monohydrate at dose of 100 , 140,180 and $200 \mathrm{mg} / \mathrm{kg}$ B.W. were injected intraperitoneally to the experimental rats. The data presented in Table 1 demonstrated that BGL at 100 $\mathrm{mg} / \mathrm{kg}$ B.W. of alloxan monohydrate was 90-120

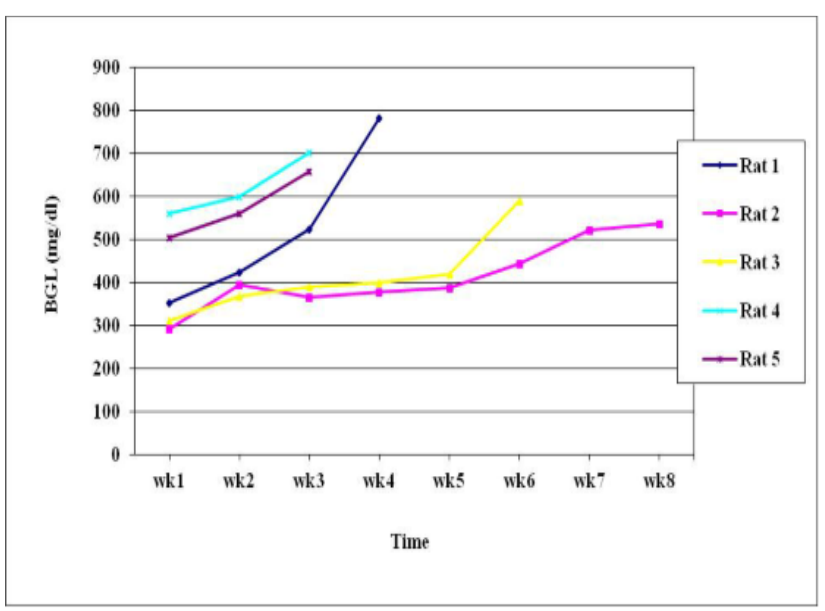

Fig. 6: Time-course evaluation of antibiabetic effect of cow's milk on 5 rats

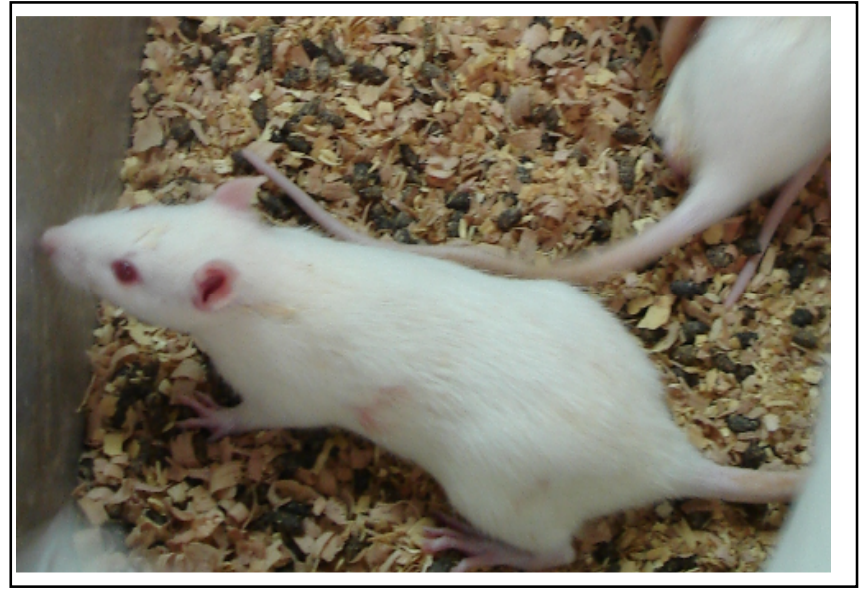

Fig. 8: White albino rat showed sign of recovery from diabetes after 5 weeks of receiving camel's milk

$\mathrm{mg} / \mathrm{dl}$ and considered as suboptimal to induce diabetes BGL at $100 \mathrm{mg} / \mathrm{kg} \mathrm{BW}$ was lower than what was previously recorded by Sushruta et al. (2006) and Dhasarathan and Theriappan (2010). The other 3 doses of alloxan monohydrate showed varying degree of severity of hyperglycemia. In the present study, alloxan monohydrate at dose $200 \mathrm{mg} / \mathrm{kg}$ B.W. was lethal and led to death of all rats within 3 days from injection. These animals suffered from severe loss of body weight, polyurea, diabetic coma and death. On contrary, Tripathi and Chandra (2009) found that 140-200 mg/kg B.W. alloxan doses were reported as 
non lethal. Our results also revealed that animals injected with alloxan at dose $180 \mathrm{mg} / \mathrm{kg} \mathrm{B.W}$. exhibited high fasting BLG with high mortality, while at dose $140 \mathrm{mg} / \mathrm{kg} \mathrm{B.W}$. resulted in a diabetic state (80 \% morbidity) and no mortality. Alloxan monohydrate at dose $140 \mathrm{mg} / \mathrm{kg} \mathrm{B}$.W. was selected as optimal dose to induce stable diabetes in rats.

Test 2: Effect of camel's milk in comparison with cow's milk on alloxan-induced diabetic rats

This study was performed to observe the role of camel's milk in achieving glycemic control in alloxan-induced diabetic rats. The results of this experiment were presented in Table 2. During the experimental period, the initial mean BGL in diabetic control group was $399.5 \pm 18.3 \mathrm{mg} / \mathrm{dl}$ and increased by the $5^{\text {th }}$ week to $488.2 \pm 20.8 \mathrm{mg} / \mathrm{dl}$. In camel's milk receiving group, diabetic rats had marked reduction in weekly BGL and one rat showed complete improvement after 8 weeks of treatment (BGL). The mean BGL came down from $429.24 \pm 57$ to $308.28 \pm$ $52.2 \mathrm{mg} / \mathrm{dl}$ by the end of $5^{\text {th }}$ week. On contrary, diabetic rats received cow's milk, showed increase in their mean BGL and 2 of them developed severe diabetes and succumbed. The mean BGL was increased from $404.6 \pm 53.6$ to $519.8 \pm 131.5 \mathrm{mg} / \mathrm{dl}$. The effect of cow's milk in our results is similar to the result recorded by Agrawal et al. (2005). This improvement may be due to presence of high concentration of insulin-like protein in camel's milk (Beg et al., 1986 and Yagil et al., 1994), According to Wangoh (1993) camel's milk does not form coagulum in acidic environment of the stomach. This lack of coagulum formation allows the camel's milk to pass through the stomach together with the specific insulin-like protein and remain available for absorption in the intestine. Also camel's milk is rich in mineral content and antioxidant (Farah, 1993). High concentrations of antioxidants may also make the insulin receptors to respond better to available insulin (Agrawal et al., 2004). Moreover, El-Said et al. (2010) reported that the pancreas of alloxaninduced rabbits receiving camel's milk showed high restoration number of islets of Langerhans among the pancreatic acini. Time-course evaluation of antibiabetic effect of camel's milk on 5 rats is depicted in Fig. 6.

In the present study, we kept continue measuring the BGL after the testing period found that the diabetic group receiving camel's milk has long survival period. All diabetic rats in positive diabetic groups succumbed after the $5^{\text {th }}$ week while in diabetic group treated with cow's milk died before $5^{\text {th }}$ week $(2$ rats developed severe diabetes and died at the $3^{\text {rd }}$ weeks). The data in Fig. 7 revealed that cow's milk had adverse effect on diabetic rats. This diabetogenicity of cow's milk may be due to low concentration of insulin-like protein in cow's milk $(16.32 \pm 5.98$ micro unit/ml) (Shehadeh et al., 2001) or it might be due to milk clot in acid environment of the stomach (Breitling, 2002). The retention of milk clots in the stomach helps to accelerate the degradation of insulin. Vaarala et al. (1999) reported that bovine insulin acts as an immunogen and the IgG anti-bovine insulin may react with human insulin and damage $\beta$ cells (Breitling, 2002).

From the result presented in our study, it could be concluded that raw camel's milk reduced BGL in diabetic rats. Thus, the therapeutic efficacy of camel's milk on alloxan-induced diabetic rats may have an importance implication for the clinical management in treatment of diabetes in target population.

\section{Authors' contribution}

Authors have formulated the research plan and conducted the study equally. Authors discussed the results, read and approved the final manuscript.

\section{Acknowledgements}

The authors are grateful to all staff at Laboratory Animals House, Assiut University-Egypt for their kind support during conducting this study.

\section{Competing interests}

None of the authors have any conflict of interest to declare.

\section{REFERENCES}

Agrawal, PP.; Swami, SC.; Beniwal, R.; Kochar, DK.; Sahani, MS.; Tuteja, FC. and Ghouri, $S K$. (2003): Effect of raw camel milk on glycemic control, risk factors and diabetes quality of life in type-1 diabetes: a randomised prospective controlled study. Journal of Camel Practices Research, 10: 45-50.

Agrawal, RP.; Kochar, DK.; Sahani, MS.; Tuteja, FC. and Ghorui, SK. (2004): Hypoglycemic activity of camel milk in streptozotocin induced diabetic rats. International Journal of Diabetes in Developing Countries, 24: 47-49.

Agrawal, RP.; Sahani, MS.; Tuteja, FC.; Ghouri, SK.; Sena, DS.; Gupta, R. and Kochar, DK. (2005): Hypoglycemic activity of camel milk in chemically pancreatectomized rats - an experimental study. International Journal of Diabetes in Developing Countries, 25: 75-79.

Beg, OU.; Von Bahr-Lindström, H.; Zaidi, ZH. and Jörnvall, H. (1986): A camel milk whey protein rich in half cystine, primary structure assessment of variations, internal repeat patterns and relationship with neurophysin and other active polypeptides. European Journal of Biochemistry, 159: 195-201. 
Bolaffi, JL.; Nowlain, RE.; Gruz, L. and Grodsky, GM. (1986): Progressive damage of cultured pancreatic islet after single early exposure to srteptozotocin. Diabetes, 35: 1027-1033.

Breitling, L. (2002): Insulin and antidiabetic activity of camel milk. Journal of Camel Practices Research, 9: 43-45.

Catchpole, B.; Kennedy, LJ.; Davison, LJ. and Others (2008): Canine diabetes mellitus: From phenotype to genotype. Journal of Small Animal Practice, 49: 4-10.

Davison, LJ.; Herrtage, ME. and Catchpole, B. (2005): Study of $253 \mathrm{dogs}$ in the United Kingdom with diabetes mellitus. Veterinary Record, 156: 467-471.

Dhasarathan, P. and Theriappan, P. (2010): Evaluation of anti-diabetic activity of Strychonous potatorum in alloxan induced diabetic rats. Journal of Medicine and Medical Sciences, 2: 670-674.

El-Said, EE.; El-Sayed, GR. and Tantawy, E. (2010): Effect of Camel Milk on Oxidative Stresses in Experimentally Induced Diabetic Rabbits. Veterinary Research Forum, 1: 30-43.

Farah, Z. (1993): Composition and characteristics of camel milk. A review. Journal of Dairy Research, 60: 603-626.

Lemhadri, A.; Zeggwagh, NA.; Maghrani, M.; Jouad, H. and Eddouks, M. (2004): Antihyperglycemic of the aqueous extract of Origanum vulgare growing wild in Tafilalet region. Journal Ethnophamacology, 92: 251256.

Li, WL.; Zheng, HC.; Bukuru, J. and De Kimpe, N. (2004): Natural medicines used in the traditional Chinese medical system for therapy of diabetes mellitus. Journal of Ethnophamacology, 92: 1-21.

Macedo, CS.; Capelletti, SM.; Mercadante, MC.; Padovani, CR. and Spadella, CT. (2002): Role of metabolic control on diabetic nephropathy. Acta Cirurgica Brasileira, 17: 37-45.

Pari, L. and Satheesh, MA. (2004): Antidiabetic activity of Boerhaavia diffusa L.: effect on hepatic key enzymes in experimental diabetes. Journal of Ethnophamacology, 91: 109-113.

Shehadeh, N.; Gelertner, L.; Blazer, S.; Perlman, R.; Solovachik, L. and Etzioni, A. (2001): Importance of insulin content in infant diet: suggestion for anew infant formula. Acta paediatrica, 90: 93-95.
Singh, MB.; Lakshminarayana, J. and Fotedar, R. (2009): Nutritional status of adult population of Raika community in Jodhupur desert district of Rajasthan. Journal of human Ecology, 26: 77-80.

Stanely-Prince, P.; Kamalakkannan, N. and Menon, VP. (2004): Antidiabetic and antihyperlipidemic effect of alcoholic Syzigium cumini seeds in aloxan induced dianbetic albino rats. Journal of Ethnophamacology, 91: 209-213.

Sushruta, K.; Satyanarayana, S.; Srinivas, N. and Sehar, JR. (2006): Evaluation of blood glucose reducing effects of aqueous extracts of the selected umbelliferous fruits used in culinary practices. Tropical Journal of Pharmaceutical Research, 5: 613-617.

Tirerney, LM.; Mcphee, SJ. and Papadakis, MA. (2002): Current medical Diagnosis and Treatment. International edition, New York: Lange Medical Books/McGraw-Hill, 12031215. ISBN 0-07-137688-7. [2] World Health, pp 1203-1215.

Tatiya, AU.; Kulkami, AS.; Surana, SJ. and Bari, ND. (2010): Antioxidant and hypolipidemic effect of Caralluma adscendens Roxb in alloxinated diabetec rats. International Journal of Pharmacology, 6: 400-406.

Tripathi, UN. and Chandra, D. (2009): The plant extracts of Momordica charantia and Trigonella foenum graecum have antioxidant and anti-hyperglycemic properties for cardiac tissue during diabetes mellitus. Oxidative Medicine and Cellular Longevity, 2: 290-296.

Wangoh, J. (1993): What steps towards camel milk technology? International Journal of Animal Science, 8:9-17.

Yagil, R. (1982): Camels and camel milk. FAO Animal Production and Health Paper, FAO of the United Nations, Via delle Terme di Caracalla, $00100 \quad$ Rome, Italy http://www.fao.org/docrep/003/X6528E/X652 8E00.HTM\#TOC

Yagil, R.; Zagorski, O.; Voncreveld, C. and Saran, A. (1994): Science and camel milk production. In: Chameaux et dromedaires, animeaux laitiers. Ed. Saint-Martin, G. Expansion scientifique Francaise, Paris, pp 75-89. 


\section{التأثير المعادل للبن الجمال علي داء السكري المستحث بمادة الالوكسان في نموذج لحيوان التجارب رشا جلال سيد ، أحمد عبل الحميل ، نصر اللين محمد عارف ، محد سبي}

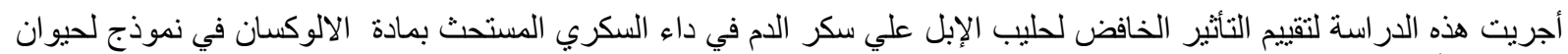

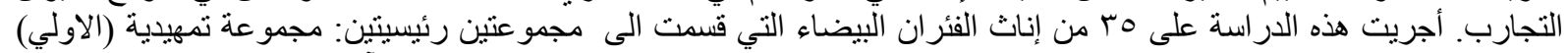

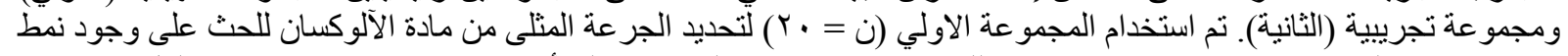

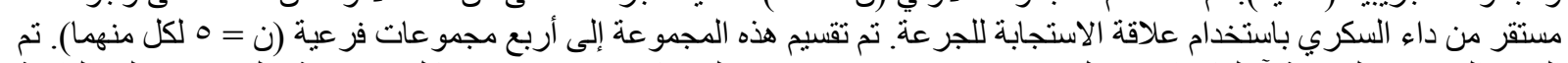

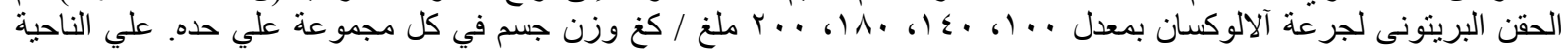

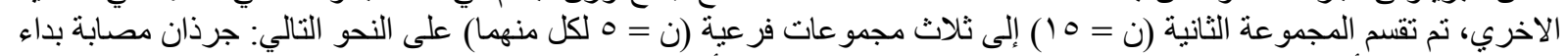

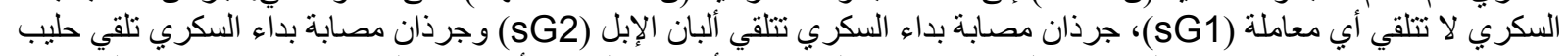

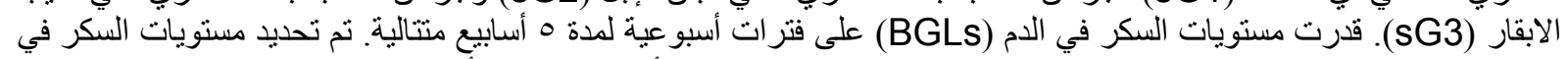

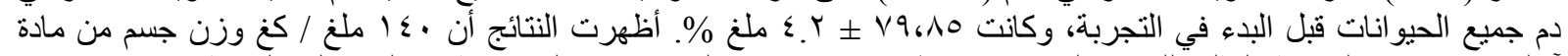

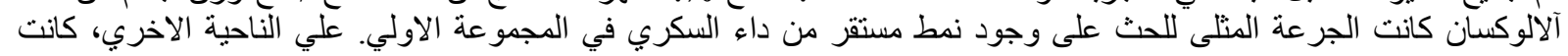

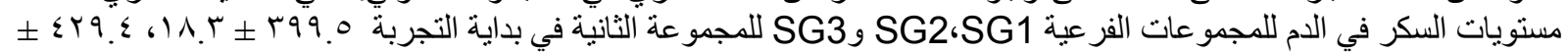

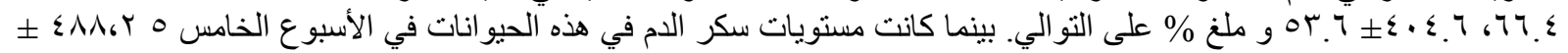

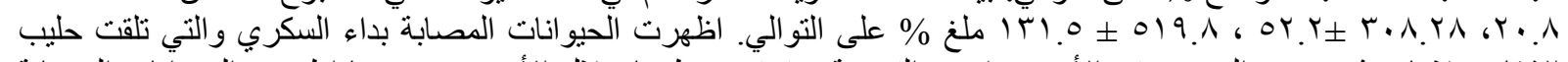

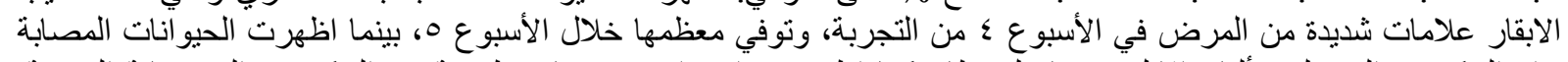

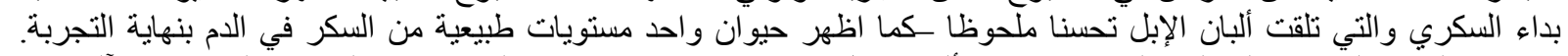

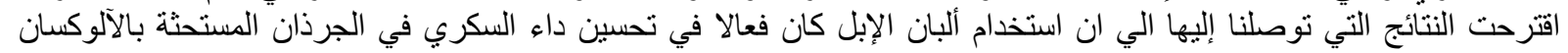
ويوصى به في كتغذية علاجية لمريض السكري. 